\title{
List of Entries
}

The Abandoned Doll (Opuštěná panenka) Josef Bor — 41

And God Saw That It Was Bad (I viděl Bůh, že je to špatné) Otto Weiss - 45

Annihilation (Zagtada) Piotr Szewc - 49

At Home with the Hitlers. The Hitlers' Kitchen (Doma u Hitlerů. Hitlerovic kuchyň) Arnošt

Goldflam - 53

The Beautiful Mrs Seidenman (Początek) Andrzej Szczypiorski — 57

The Black Seasons (Czarne sezony) Michat Gtowiński — 61

A Black Solstice (Čierny slnovrat) Klára Jarunková — 66

Black Torrent (Czarny potok) Leopold (Wincenty) Buczkowski - 70

The Black Tree’s Memory (Černá pamět stromu) Lumír Čivrný — 73

The Boarding House (Pensjonat) Piotr Paziński — 76

Boundary Marker (Kamień graniczny) Piotr Matywiecki - $\mathbf{8 0}$

A Box of Lives (Krabice živých) Norbert Frýd - 84

Bread for the Departed (Chleb rzucony umartym) Bogdan Wojdowski - 88

A Christmas Legend from the Ghetto (Vánoční legenda z ghetta) František Kafka - 92

The Clerical Republic (Farská republika) Dominik Tatarka — 95

Colors (Barvy) Jiři Weil — 99

Concert on the Island (Koncert na ostrově) Jaroslav Seifert — 102

Confession (Spowiedź) Calek Perechodnik — 106

The Court Jesters (Dvorní šašci) Viktor Fischl/Avigdor Dagan — 110

The Cremator (Spalovač mrtvol) Ladislav Fuks — 113

Crow Songs (Vraní zpěvy) Radek Malý — 117

The Day of Wrath (Dzień gniewu) Roman Brandstaetter — 121

Death Is Called Engelchen (Smrt' sa volá Engelchen) Ladislav Mňačko — 125

Death of a Liberal (Śmierć liberała) Artur Sandauer — 129

The Death of the Beautiful Deer (Smrt krásných srnců) Ota Pavel — 132

The Devil's Workshop (Chladnou zemí) Jáchym Topol — 136

Diamonds of the Night (Démanty noci) Arnošt Lustig — 139

Diary of Love (Pamiętnik miłości) Stanisław Wygodzki — 143

Doctor Josef's Beauty (Ślicznotka doktora Josefa) Zyta Rudzka — 147

Doctor Mráz (Doktor Mráz) Denisa Fulmeková — 150

The Earth Under Your Feet (Zem pod nohami) Mikuláš Kováč — 154

Elegy for 77,297 Victims (Žalozpěv za 77297 obětî) Jiři Weil — 157

Elegy for the Little Jewish Towns (Elegia miasteczek żydowskich) Antoni Stonimski — 161

The Elephants in Mauthausen (Slony v Mauthausene) Ján Johanides — 165

Emma and the Death's Head Hawkmoth (Ema a Smrtihlav) Peter Krištúfek — 169

The Empty Field (Puste pole) Tadeusz Hotuj — 172

The Escape from Yasnaya Polyana (Ucieczka z Jasnej Polany) and Shakespeare (Szekspir)

Adolf Rudnicki — 175

An Excursion to the Museum (Wycieczka do muzeum) Tadeusz Różewicz - 179

A Farewell to Maria (Pożegnanie z Marią) Tadeusz Borowski — 182

The Final Station (Umschlagplatz) Jarostaw Marek Rymkiewicz — 186

The Flytrap Factory (Fabryka muchołapek) Andrzej Bart — 190

The Fourth Language (Štvrtá reč) Pavel Vilikovský — 194

Frascati: An Apotheosis of Topography (Frascati. Apoteoza topografii) Ewa Kuryluk — 197

From the Abyss: Memories from the Camp (Z otchtani: Wspomnienia z lagru) Zofia Kossak - 200

God's Horse (Koń Pana Boga) Wilhelm Dichter — 203

Ә Open Access. () 2021 Elisa-Maria Hiemer et al., published by De Gruyter. (cc)BY-NC-ND This work is licensed under a Creative Commons Attribution-NonCommercial-NoDerivatives 4.0 License.

https://doi.org/10.1515/9783110671056-203 
Hannah (Hana) Alena Mornštajnová — 207

The Holocaust (Holokaust) Viliam Klimáček — 211

Holy Week: A Novel of the Warsaw Ghetto Uprising (Wielki Tydzień) Jerzy Andrzejewski — 214

A Human Matter (Rzecz ludzka) Mieczystaw Jastrun — 218

I Didn't Want to Be a Jew (Nechcel som byt' žid) Juraj Špitzer — 221

It Happened on the First September (or Whenever) (Stalo sa prvého septembra [alebo inokedy])

Pavol Rankov - 225

Italian High Heels (Włoskie szpilki) Magdalena Tulli — 229

The Jewish War and The Victory (Żydowska wojna, Zwycięstwo) Henryk Grynberg — 233

The Land of Forgetting (Krajina zabudnutia) Anton Baláž — 237

The Land without God (Země bez Boha) Ota B. Kraus - 241

The Last Cyclist (Poslední cyklista) Karel Švenk — 245

The Last Thing (Posledná vec) Leopold Lahola — 249

Lessons in Love and Dancing (Hodina tance a lásky) Pavel Kohout - 253

Life with a Star (Život s hvězdou) Jiři Weil — 256

The Lilies of Erika (Erikine l'alie) Vincent Šikula — 260

Lily of the Valley: Rudolf Dilong’s Forbidden Love (Konvália: Zakázaná láska Rudolfa Dilonga)

Denisa Fulmeková — 263

The Liver of Prometheus (Prometheova játra) Jiři Kolář — 266

Medallions (Medaliony) Zofia Natkowska — 270

The Menorah (Sedmiramenný svícen) Josef Škvorecký — 274

Miracle in the Darkhouse (Zázrak v černém domě) Milan Uhde — 278

Modern Nativity Play (Jasetka-moderne) Ireneusz Iredyński — 281

Money from Hitler (Peníze od Hitlera) Radka Denemarková — 285

More Gas, Comrades! (Więcej gazu, Kameraden!) Krystian Piwowarski — 289

The Most Important Particle (Ta najważniejsza cząsteczka) Stanisław Benski — 292

Mr Theodore Mundstock (Pan Theodor Mundstock) Ladislav Fuks - 295

Night of the Living Jews (Noc żywych Żydów) Igor Ostachowicz - 299

The Old Man and Fate (Starý pán a osud) Peter Karvaš — 303

Our Class : XIV Lessons from History (Nasza klasa: historia w XIV lekcjach) Tadeusz

Stobodzianek -306

The Peasant (Sedliak) František Švantner — 310

A Pending Matter (Nevybavená záležitost') Jana Juráňová — 314

The Pianist (Śmierć miasta) Wtadystaw Szpilman — 317

A Piece About Mother and Fatherland (Utwór o Matce i Ojczyźnie) Bożena Keff — 321

Plague in Athens (Mor v Athénách) Jiři Kolář — 325

Pocket Atlas of Women (Kieszonkowy atlas kobiet) Sylwia Chutnik - 329

Postscriptum (Postscriptum) Maria Nurowska - 334

A Prayer for Katerina Horovitzova (Modlitba pro Kateřinu Horovitzovou) Arnošt Lustig — 338

A Private Conversation (Soukromý rozhovor) Hana Bořkovcová — 342

Proofs of Existence (Dowody na istnienie) Hanna Krall — 346

A Reading of Ashes (Odczytanie popiołów) Jerzy Ficowski - 350

Romeo and Juliet and the Darkness (Romeo, Julie a tma) Jan Otčenášek — 354

Samson (Samson) Kazimierz Brandys - 358

A Scrap of Time (Skrawek czasu) Ida Fink - 361

Selected Poetry (Poezje wybrane) Wtadystaw Broniewski — 365

Selected Poetry (Poezje wybrane) Czestaw Mitosz — $\mathbf{3 6 9}$

Selected Poetry (Wicrsze wybrane) Wisława Szymborska — 373

The Shop on Main Street (Obchod na korze) Ladislav Grosman — 376 
Sidra Noach (Sidra Noach) David Jan Novotný — 380

The Sixth Battalion, On Guard! (Šiesty prápor, na stráž!) Emil F. Knieža — 384

Society for the Prevention of Cruelty to Animals (Spolek pro ochranu zvířat) Jiři Robert Pick

388

The Song Will Survive... (Pieśń ujdzie cało...) Michat M. Borwicz — 392

The Sound of the Sundial (Zvuk slunečních hodin) Hana Andronikova - 396

St. Elizabeth's Square (Námestie svätej Alžbety) Rudolf Jašík — $\mathbf{4 0 0}$

The Stein Brothers Are in Town (Ve městě jsou bratři Steinové) Věra Kalábová — 404

The Subtenant (Sublokatorka) Hanna Krall — 407

The Suitcase (Walizka) Małgorzata Sikorska-Miszczuk — 411

Sweet Theresienstadt (Sladký Theresienstadt) Arnošt Goldflam — 414

The Terezín Requiem (Terezínské Rekviem) Josef Bor — 418

There Used to Be a Jewish Women, There Is No More Jewish Woman Now (Była Żydówka, nie ma Żydówki) Marian Pankowski

Trap with a Green Fence (Treblinka, slovo jak z dětské říkanky) Richard Glazar — 426

Tumult (Rejwach) Mikołaj Grynberg — 430

Tworki (Tworki) Marek Bieńczyk — 434

We, Polish Jews (My, Żydzi polscy) Julian Tuwim — 438

What I Read to the Dead (Co czytałem umarłym) Władysław Szlengel — 442

White Elephants (0 bílých slonech) Irena Dousková — 446

Without Beauty, without a Collar (Bez krásy, bez límce) Hana Bělohradská — 449

The Woman Rabbi (Rabínka) Anna Grusková — 452

The Wrecked Temple in Me (Vo mne zbúraný chrám) Milan Richter — 456 
